\title{
PERAN INTERNAL AUDIT DALAM IMPLEMENTASI ENTERPRISE RISK MANAGEMENT BERUPA PELAPORAN KERUSAKAN PROSEDUR RISIKO
}

\author{
Indarti \\ Universitas Lancang Kuning, Jl. Yos Sudarso KM. 08 Rumbai, Pekanbaru, Riau. \\ email: indarti.sam9@gmail.com
}

\begin{abstract}
Implementation of Enterprise Risk Management (ERM) by Internal Audit in an organization or company becomes important because Internal Audit is expected to help the organization achieve its objectives by approaching systematic and discipline to evaluate and improve the effectiveness of risk management, control, and governance process. As for which affects it is the involvement of internal auditors, the relationship of the audit committee with the internal auditor, and ERM.

This study aims to analyze the involvement of Internal Audit in Enterprise Risk management implementation. Internal auditors should assist both management and audit committees in risk management responsibilities and supervisory roles by examining, evaluating, reporting and recommending improvements to the adequacy and effectiveness of risk management processes. An interesting issue is whether internal auditors involved in corporate risk management have a link to the willingness of internal auditors to report to the audit committee.

The population in this study are the internal auditors and audit committees who working in companies manufacturing and financial services. The reason for determining the company is because the researcher wants to know how internal audit is involved in ERM implementation on that entity. The sample used in this research is internal auditor at private company and at Banking in this case internal auditor at local bank.

The analytical method used is multiple regression analysis with SPSS version 23 program. The analysis technique used in this research is descriptive statistical analysis, classical assumption test, F-statistic hypothesis test to test influence together with 5\% confidence level and use t-statistics to test partial regression coefficients. This research was conducted to analyze how much influence the role of Internal Audit in applying Enterprise Risk Management in the implementation of Audit.

The result of this research is that the high level of internal auditor involvement in Enterprise Risk management implementation has no significant and significant impact on reporting of damage to risk management procedures. This indicates that the role of internal auditors in corporate risk management does not affect the reporting of damage to corporate risk management procedures. While the characteristics of strong relationships between internal auditors and audit committees positively and significantly influence the reporting of risk procedures, this indicates that internal audits that have strong internal audit-audit committee relationships strongly support internal auditors who have high involvement to report damage Greater risk procedures.
\end{abstract}

Keyword: Enterprise Risk Management, Internal Audit. 


\begin{abstract}
Abstrak
Pelaksanaan Enterprise Risk Management (ERM) oleh Internal Audit dalam suatu organisasi atau perusahaan menjadi hal yang penting karena Internal Audit diharapkan dapat membantu organisasi mencapai tujuannya dengan melakukan pendekatan sistematis dan disipilin untuk mengevaluasi dan meningkatkan efektifitas manajemen risiko, pengendalian, dan proses tata kelola. Adapun yang mempengaruhi hal tersebut adalah keterlibatan auditor internal, keterkaitan komite audit dengan auditor internal, dan ERM itu sendiri.

Penelitian ini bertujuan untuk menganalisis keterlibatan Internal Audit dalam implementasi Enterprise Risk management. Auditor internal harus membantu baik manajemen maupun komite audit dalam tanggung jawab manajemen risiko dan peran pengawasan dengan memeriksa, mengevaluasi, pelaporan dan merekomendasikan perbaikan pada kecukupan dan efektivitas proses manajemen risiko. Isu yang menarik adalah apakah auditor internal yang terlibat dalam manajemen risiko perusahaan memiliki keterkaitan pada kesediaan auditor internal untuk melapor ke komite audit. Populasi dalam penelitian ini adalah para auditor internal beserta komite audit bekerja di perusahaan-perusahaan baik itu manufaktur maupun jasa keuangan. Alasan penentuan perusahaan tersebut adalah dikarenakan peneliti ingin mengetahui bagaimana internal audit terlibat dalam pelaksanaan ERM pada entitas tersebut. Sampel yang digunakan dalam penelitian ini adalah auditor internal pada perusahaan swasta dan pada Perbankan dalam hal ini auditor internal pada bank daerah.

Metode analisis yang digunakan adalah analisis regresi berganda dengan program SPSS versi 23. Teknik analisis yang digunakan pada penelitian ini adalah analisis statistik deskriptif, uji asumsi klasik, uji hipotesis F-statistik untuk menguji pengaruh secara bersama-sama dengan tingkat kepercayaan 5\% serta menggunakan t-statistik untuk menguji koefisien regresi parsial. Penelitian ini dilakukan untuk menganalisis seberapa besar pengaruh peran Internal Audit dalam menerapkan Enterprise Risk Management dalam pelaksanan Auditnya.

Hasil pada penelitian ini adalah bahwa tingkat keterlibatan auditor internal yang tinggi pada implementasi Enterprise Risk Management perusahaan tidak berpengaruh dan signifikan terhadap pelaporan kerusakan prosedur manajemen risiko perusahaan. Hal ini menunjukkan bahwa peran internal auditor dalam manajemen risiko perusahaan tidak mempengaruhi pelaporan kerusakan prosedur manajemen risiko perusahaan. Sedangkan karakteristik hubungan yang kuat antara auditor internal dengan komite audit berpegaruh positif dan signifikan terhadap pelaporan kerusakan Prosedur risiko, hal ini menunjukkan bahwa audit internal yang memiliki hubungan audit internal-komite audit yang kuat akan sangat mendukung internal auditor yang memiliki keterlibatan yang tinggi untuk melaporkan kerusakan prosedur risiko yang lebih besar.
\end{abstract}

Kata Kunci: Enterprise Risk Management, Internal Audit.

\section{Pendahuluan}

\section{Latar Belakang Masalah}

Sebagaimana yang kita ketahui bahwa krisis ekonomi yang melanda Indonesia telah memberikan pelajaran yang berharga bagi kondisi perekonomian Indonesia. Praktek- praktek tidak terpuji dari para pelaku ekonomi dalam kurun waktu sebelum krisis akibat tidak adanya standar etika usaha dan transparansi dalam pengelolaan perusahaan membuat situasi ekonomi Indonesia semakin memburuk. Perkembangan sektor korporasi baik perusahaan swasta maupun perusahaan negara di Indonesia banyak yang belum 
diikuti dengan perangkat praktek-praktek usaha yang sehat. Pertumbuhan korporasi selama ini ternyata belum sepenuhnya dibangun di atas landasan korporasi yang kuat dan efektifitas operasional yang baik, sehingga banyak perusahaan yang tidak mampu bertahan menghadapi dampak krisis yang terjadi, padahal pada satu sisi perusahaanperusahaan banyak yang tergantung pada modal ekstern (ekuitas dan pinjaman) untuk pembiayaan kegiatan, melakukan investasi dan menciptakan pertumbuhan, sementara pada sisi lain perusahaan harus dapat memastikan investor atau kreditur bahwa danadananya digunakan secara tepat dan seefisien mungkin selain memastikan bahwa pengelola perusahaan bertindak hal-hal yang terbaikuntuk kepentingan peru-sahaan.

Untuk memastikan bahwa pengelolaan operasi perusahaan berjalan dengan baik dan dalam rangka penciptaan nilai perusahaan (value creation), maka diperlukan sistemsistem pendukung. Di antara sistem-sistem pendukung tersebut adalah keberadaan fungsi audit internal pada satu sisi dan diterapkannya manajemen risiko (risk management) pada keseluruhan operasi perusahaan disisi lainnya. Pembentukan fungsi audit internal perusahaan pada awalnya merupakan bagian dari upaya perusahaan untuk memiliki, menerapkan dan memelihara pengendalian internal. Pengendalian internal merupakan suatu proses yang dipengaruhi oleh DeWan Komisaris, manajemen dan personal lainnya yang dirancang untuk memberikan keyakinan memadai mengenai efektivitas dan efisiensi operasi, pelaporan keuangan yang dapat dipercaya, dan kepatuhan terhadap peraturan perundang-undangan (COSO, 2002).

Dalam perkembangannya, keberadaan fungsi Audit Internal itu sendiri menjadi sangat strategis bagi perusahaan karena peranannya sebagai mata dan telinga bagi perusahaan dan menjadi bagian utama dalam sistem peringatan dini (early warning system) perusahaan. Audit internal merupakan aktifitas konsultasi dan penjaminan yang obyektif dan independen yang dirancang untuk memberikan nilai tambah serta meningkatkan operasi organisasi guna membantu organisasi dalam mencapai tujuannya, dengan menggunakan suatu pendekatan yang terdisiplin dan sistematis untuk mengevaluasi dan meningkatkan efektifitas manajemen risiko, pengendalian dan proses tata kelola perusahaan, The Professional Practice Framework oleh The IIA Research Foundation Januari 2004 (The Institute of Internal Auditors) Namun demikian tidak ada jaminan pula bahwa memiliki fungsi audit internal maka operasi perusahaan akan berjalan efektif dan efisien. Kerap terjadi ketidak efektifan fungsi audit internal perusahaan, karena fungsi audit internal dianggap hanya merupakan formalitas belaka, padahal eksistensi fungsi audit internal se-yogya-nya adalah untuk menilai efektivitas praktek-praktek yang sehat dalam perusahaan termasuk pada para anggota organisasi termasuk interaksinya dengan lingkungan selain sebagai media untuk mengefektifkan kebijakan, metode, prosedur, program dan alat dalam mencapai tujuan perusahaan.

Risiko merupakan potensi terjadinya suatu peristiwa-peristiwa yang dapat menimbulkan kerugian yang tidak diharapkan terjadi. Dalam kaitannya dengan bisnis, maka risiko merupakan suatu kondisi atau ancaman yang secara langsung/tidak langsung akan mempengaruhi atau berdampak buruk terhadap kemampuan perusahaan dalam mencapai tujuannya, sedangkan manajemen risiko merupakan suatu proses perbaikan berkesinambungan (continous improvement) yang mengarah langsung pada pengaruh-pengaruh buruk, identifikasi risiko, perlakuan risiko dan pemantauan atas risiko (Ernst \& Young. 2005. Business Risk Service: Enterprise Risk Management). Akhir-akhir ini pengelolaan risiko menjadi lebih penting dan dominan, sehingga dalam beberapa konteks kebutuhan akan pertimbangan risiko dan manajemen risiko menjadi lebih menonjol dan menjadi suatu kesatuan yang lebih luas Enterprise wide Risk Management, (Amin Widjaya Tunggal, 2003), sehingga diposisikan berdiri sendiri atau berkorelasi dengan konteks audit internal. Dalam hal ini Enterprise Risk Management adalah suatu proses 
yang sistematis dalam mengkoordinasikan antara setiap manajemen risiko yang ada di dalam suatu orga-nisasi (Ernst \& Young. 2005. Business Risk Service: Enterprise Risk Management).

Ikatan Auditor Internal (Institute of Internal Auditors - IIA) dikutip oleh Messier (2005), mendefenisikan audit internal sebagai berikut: Audit intern adalah aktivitas independen, keyakinan obyektif, dan konsultasi yang dirancang untuk menambah nilai dan meningkatkan operasi organisasi. Audit intern ini membantu organisasi mencapai tujuannya dengan melakukan pendekatan sistematis dan disipilin untuk mengevaluasi dan meningkatkan efektifitas manajemen risiko, pengendalian, dan proses tata kelola. Definisi ini mengandung pengertian bahwa audit intern merupakan suatu aktivitas yang dilakukan untuk membantu manajemen dalam penyediaan informasi, dengan tujuan akhir yaitu menambah nilai perusahaan. Pelaksanaan audit intern dilakukan secara independen dan objektif yang berarti tidak terpengaruh oleh pihak manapun dan tidak terlibat dalam pelaksanaan kegiatan yang diaudit. Hasil audit yang diperoleh dari pelaksanaan audit intern secara independen dan obyektif tersebut akan dapat diandalkan oleh para pengguna informasi.

Pada tahun 2004, Committee of Sponsoring Organisations (COSO) merilis suatu kerangka kerja yang terintegrasi yaitu Enterprise Risk Management (ERM). Sejak saat itu, telah ada gerakan global menuju suatu pendekatan luas mengenai risiko manajemen untuk perusahaan dengan auditor internal memainkan peran 3 kunci dalam memberikan jaminan baik dan jasa konsultasi sehubungan dengan manajemen risiko dalam organisasi mereka (Sarens dan De Beelde, 2006). Keterlibatan audit internal dalam ERM dapat menambah nilai organisasi tapi juga menimbulkan risiko yang akan mengganggu organisasi tersebut. Risiko tersebut adalah timbulnya kompromi dari independensi dan objektivitas internal auditor tersebut. Menyadari kemungkinan hal ini, IIA mengeluarkan surat pernyataan yang menggambarkan peran inti audit internal dalam hal ERM.
Pernyataan tersebut berisikan peranan audit yang sah yang dapat melaksanakan penyediaan pengamanan pada tempatnya, dan peran yang tidak seharusnya dilakukan dalam audit (IIA, 2004b).

\section{Motivasi Penelitian}

Peningkatan keterlibatan internal audit dalam ERM dan kekhawatiran bahwa hal ini dapat menimbulkan ancaman terhadap objektivitas audit internal, memberikan motivasi kunci dalam penelitian ini. Ketika mengumumkan rilis dari kerangka COSO, IIA mengeluarkan pernyataan mengomentari peran auditor internal dalam manajemen risiko (IIA, 2004a). Kutipan berikut dari pernyataan yang menegaskan bahwa IIA mendukung peran aktif untuk auditor internal dalam ERM, termasuk membuat rekomendasi untuk meningkatkan risiko proses organisasi: Auditor internal harus membantu baik manajemen maupun komite audit dalam tanggung jawab manajemen risiko dan peran pengawa dengan memeriksa, mengevaluasi, pelaporan dan merekomendasikan perbaikan pada kecukupan dan efektivitas proses manajemen risiko. Isu yang menarik adalah apakah auditor internal yang terlibat dalam manajemen risiko perusahaan memiliki keterkaitan pada kesediaan auditor internal untuk melapor ke komite audit. Dalam konteks penelitian ini, ada dua situasi yang harus dipertimbangkan. Kondisi yang pertama adalah ketika auditor internal tidak secara langsung terlibat dalam pelaksanaan prosedur risiko, auditor tersebut hanya memberi saran kepada komite audit mengenai rincian dalam prosedur. Hal itu melibatkan pelaporan negatif pada rekanrekan (yaitu staf manajemen risiko). Kondisi yang kedua, ketika auditor internal sangat terlibat dalam pelaksanaan prosedur risiko, auditor melaporkan apapun secara rinci kepada komite audit termasuk pengakuan kelemahan kinerja mereka sendiri. Keterlibatan dalam kegiatan konsultasi yang terkait dalam ERM menimbulkan ancaman yang signifikan untuk objektivitas dalam bentuk self-review, tekanan sosial dan 
keakraban (Brody dan Lowe, 2000; Ahlawat dan Loowe, 2004; Plumlee, 1985).

Berdasarkan pembahasan di atas, motivasi pada penelitian ini ingin mengetahui bagaimana pengaruh keterlibatan internal dalam melaporkan rincian pelaporan kerusakan prosedur risiko kepada komite audit ketika Internal Audit tersebut terlibat dalam pelaksanaan Enterprise Risk Management (E$\mathrm{RM})$ atau pelaksanaan manajemen risiko.

\section{Pertanyaan Penelitian}

Berdasarkan uraian di atas, terdapat beberapa hal yang dapat mempengaruhi berjalannya ERM dalam suatu organisasi atau perusahaan. Beberapa hal yang mempengaruhi hal tersebut adalah keterlibatan auditor internal, keterkaitan komite audit dengan auditor internal, dan ERM itu sendiri. Berdasarkan uraian di atas, maka masalah penelitian ini dirumuskan dalam bentuk pertanyaan sebagai berikut:

1. Apakah peran inti Internal Audit mempunyai pengaruh dalam pelaksanaan Enterprise Risk Management (ERM) berupa pelaporan kerusakan prosedur Risiko?

2. Apakah peran sah intenal audit dengan pengamanan yang tepat mempunyai pengaruh dalam pelaksanaan Enterprise Risk Management (ERM) berupa pelaporan kerusakan prosedur Risiko?

3. Apakah Peran yang tidak harus dilakukan oleh Internal Audit mempunyai pengaruh dalam pelaksanaan Enterprise Risk Management (ERM) berupa pelaporan kerusakan prosedur Risiko?

4. Apakah Objectivitas Internal Audit berpengaruh terhadap dalam pelaksanaan Enterprise Risk Management (ERM) berupa pelaporan kerusakan prosedur Risiko?

5. Apakah peran sah intenal audit dengan safeguard, Peran yang tidak harus dilakukan, dan Objectivitas Internal Audit berpengaruh secara bersamaan terhadap dalam pelaksanaan Enterprise Risk $M a-$ nagement (ERM) berupa pelaporan kerusakan prosedur Risiko?

\section{Tujuan Penelitian}

Tujuan dari penelitian ini adalah:

a). Untuk mengetahui peran inti internal audit mempunyai pengaruh dalam pelaksanaan Enterprise Risk Management (E$\mathrm{RM}$ ) berupa pelaporan kerusakan prosedur Risiko.

b). Untuk mengetahui peran sah intenal audit dengan pengamanan yang tepat mempunyai pengaruh dalam pelaksanaan Enterprise Risk Management (ERM) berupa pelaporan kerusakan prosedur Risiko.

c). Untuk mengetahui peran yang tidak harus dilakukan oleh internal audit mempunyai pengaruh dalam pelaksanaan Enterprise Risk Management (ERM) berupa pelaporan kerusakan prosedur Risiko.

d). Untuk mengetahui Objectivitas Internal Audit berpengaruh terhadap dalam pelaksanaan Enterprise Risk Management (ERM) berupa pelaporan kerusakan prosedur Risiko?

Untuk mengetahui intenal audit dengan safeguard, Peran yang tidak harus dilakukan, dan Objectivitas Internal Audit berpengaruh secara bersamaan terhadap dalam pelaksanaan Enterprise Risk Management (ERM) berupa pelaporan kerusakan prosedur Risiko.

\section{Tinjauan Pustaka}

Pada bab ini akan dijelaskan mengenai pengertian umum yang digunakan untuk menganalisis tingkat keterlibatan internal audit dalam ERM dalam suatu perusahaan. Selain itu, dalam telaah pustaka juga dibahas hasil-hasil penelitian sebelumnya yang sejenis. Oleh karena itu, secara sistematis bab ini mencakup pengertian umum, penelitian terdahulu, kerangka pemikiran, dan hipotesis.

\section{Landasan Teori}

Pada bagian pengertian umum akan dijelaskan pengertian-pengertian yang mendukung dalam perumusan hipotesis penelitian ini, serta membantu dalam 
menganalisis hasil penelitian yang didapat dalam penelitian. Sedangkan untuk telaah pustaka yang berasal dari penelitian terdahulu, akan dijelaskan tentang hasil-hasil penelitian yang didapat oleh peneliti terdahulu yang berkaitan dengan keterlibatan internal audit dalam ERM. Berikut ini landasan teori dan penelitian terdahulu yang berkaitan dengan penelitian ini.

\section{Teori Peran}

Teori peran (Role Theory) adalah teori yang merupakan perpaduan antara teori, orientasi, maupun disiplin ilmu. Selain dari psikologi, teori peran berawal dari sosiologi dan antropologi (Sarwono, 2002). Dalam ketiga ilmu tersebut, istilah 'peran' diambil dari dunia teater. Dalam teater, seorang aktor harus bermain sebagai seorang tokoh tertentu dan dalam posisinya sebagai tokoh itu ia diharapkan untuk berperilaku secara tertentu. Posisi aktor dalam teater (sandiwara) itu kemudian dianalogikan dengan posisi seseorang dalam masyarakat. Sebagaimana halnya dalam teater, posisi orang dalam masyarakat sama dengan posisi aktor dalam teater, yaitu bahwa perilaku yang diharapkan daripadanya tidak berdiri sendiri, melainkan selalu berada dalam kaitan dengan adanya orang-orang lain yang berhubungan dengan orang atau aktor tersebut. Dari sudut pandang inilah disusun teoriteori peran. Linton (1936, dalam Cahyono, 2008), seorang antropolog, telah mengembangkan teori peran.

Teori Peran menggambarkan interaksi sosial dalam terminologi aktor-aktor yang bermain sesuai dengan apa yang ditetapkan oleh budaya. Sesuai dengan teori ini, harapan-harapan peran merupakan pemahaman bersama yang menuntun individu untuk berperilaku dalam kehidupan sehari-hari. Menurut teori ini, seseorang yang mempunyai peran tertentu misalnya sebagai dokter, mahasiswa, orang tua, wanita, dan lain sebagainya, diharapkan agar seseorang tadi berperilaku sesuai dengan peran tersebut. Mengapa seseorang mengobati orang lain, karena dia adalah seorang dokter. Jadi ka- rena statusnya adalah dokter maka dia harus mengobati pasien yang datang kepadanya dan perilaku tersebut ditentukan oleh peran sosialnya. Kemudian, sosiolog yang bernama Elder (1975) dalam Mustofa (2006) membantu memperluas penggunaan teori peran dengan menggunakan pendekatan yang dinamakan 'lifecourse' yang artinya bahwa setiap masyarakat mempunyai harapan kepada setiap anggotanya untuk mempunyai perilaku tertentu sesuai dengan kategori-kategori usia yang berlaku dalam masyarakat tersebut. Contohnya, sebagian besar warga Amerika Serikat akan menjadi murid sekolah ketika berusia empat atau lima tahun, menjadi peserta pemilu pada usia delapan belas tahun, bekerja pada usia tujuh belas tahun, mempunyai istri/suami pada usia dua puluh tujuh, pensiun pada usia enam puluh tahun. Di Indonesia berbeda, usia sekolah dimulai sejak usia tujuh tahun, punya pasangan hidup sudah bisa sejak usia tujuh belas tahun, dan pensiun pada usia lima puluh lima tahun. Urutan tadi dinamakan 'tahapan usia’ (age grading). Dalam masyarakat kontemporer kehidupan manusia dibagi ke dalam masa kanak-kanak, masa remaja, masa dewasa, dan masa tua, dimana setiap masa mempunyai bermacam-macam pembagian lagi. Selain itu, Kahn et al. (dalam Ahmad dan Taylor, 2009) juga mengenalkan teori peran pada literatur perilaku organisasi. Mereka menyatakan bahwa sebuah lingkungan organisasi dapat mempengaruhi harapan setiap individu mengenai perilaku peran mereka. Harapan tersebut meliputi norma-norma atau tekanan untuk bertindak dalam cara tertentu. Individu akan menerima pesan tersebut, menginterpretasikannya, dan merespon dalam berbagai cara.

Masalah akan muncul ketika pesan yang dikirim tersebut tidak jelas, tidak secara langsung, tidak dapat diinterpretasikan dengan mudah, dan tidak sesuai dengan daya tangkap si penerima pesan. Akibatnya, pesan tersebut dinilai ambigu atau mengandung unsur konflik. Ketika hal itu terjadi, individu akan merespon pesan tersebut dalam cara yang tidak diharapkan oleh si pengirim pesan. Harapan akan peran tersebut dapat 
berasal dari peran itu sendiri, individu yang mengendalikan peran tersebut, masyarakat, atau pihak lain yang berkepentingan terhadap peran tersebut. Setiap orang yang memegang kewenangan atas suatu peran akan membentuk harapan tersebut. Individu atau pihak yang berbeda dapat membentuk harapan yang mengandung konflik bagi pemegang peran itu sendiri. Oleh karena setiap individu dapat menduduki peran sosial ganda, maka dimungkinkan bahwa dari beragam peran tersebut akan menimbulkan persyaratan/harapan peran yang saling bertentangan (Ahmad dan Taylor, 2009). Hal tersebut yang dikenal sebagai konflik peran. Sebagaimana diungkapkan juga oleh Kats dan Kahn (dalam Damajanti, 2003) bahwa individu akan mengalami konflik dalam dirinya apabila terdapat dua tekanan atau lebih yang terjadi secara bersamaan yang ditujukan pada diri individu tersebut. Konflik pada setiap individu disebabkan karena individu tersebut harus menyandang dua peran yang berbeda dalam waktu yang sama. Teori peran juga menyatakan bahwa ketika perilaku yang diharapkan oleh individu tidak konsisten, maka mereka dapat mengalami stres, depresi, merasa tidak puas, dan kinerja mereka akan kurang efektif daripada jika pada harapan tersebut tidak mengandung konflik. Jadi, dapat dikatakan bahwa konflik peran dapat memberikan pengaruh negatif terhadap cara berpikir seseorang. Dengan kata lain, konflik peran dapat menurunkan tingkat komitmen independensi seseorang (Ahmad dan Taylor, 2009). Adapun ambiguitas peran merupakan sebuah konsep yang menjelaskan ketersediaan informasi yang berkaitan dengan peran. Pemegang peran harus mengetahui apakah harapan tersebut benar dan sesuai dengan aktivitas dan tanggung jawab dari posisi mereka. Selain itu, individu juga harus memahami apakah aktivitas tersebut telah dapat memenuhi tanggung jawab dari suatu posisi dan bagaimana aktivitas tersebut dilakukan (Ahmad dan Taylor, 2009). Sama halnya dengan konflik peran Kahn et al., (dalam Ahmad dan Taylor, 2009) mengemukakan bahwa ambiguitas peran juga dapat meningkatkan kemungkinan seseorang menjadi merasa tidak puas dengan perannya, mengalami kecemasan, memutarbalikkan fakta, dan kinerjanya menurun. Selain itu, Kahn et al., (dalam Ahmad dan Taylor, 2009) juga menjelaskan bahwa ambiguitas peran dapat meningkat ketika kompleksitas organisasi melebihi rentang pemahaman seseorang.

\section{Definisi Internal Audit}

Menurut Institute of Internal Auditors mengenai pengertian audit internal: "Internal auditing is an independent appraisal function established within an organization to examine and evaluate its activities as a service in the organization".

Dari pengertian tersebut kita dapat menyimpulkan tujuh kunci audit internal, yaitu:

a). Independent, bahwa audit bersifat bebas dari pembatasan ruang lingkup dan efektivitas hasil audit yang berupa temuan dan pendapat.

b). Appraisal, bahwa keyakinan penelitian audit atas kesimpulan yang dibuatnya.

c). Established, Pengakuan perusahaan atas peranan audit internal.

d). Examine and evaluate, bahwa kegiatan audit internal sebagai auditor menguji serta menilai terhadap fakta-fakta yang ditemukan dalam perusahaan.

e). Its Activities, bahwa ruang lingkup pekerjaan audit internal mencakup seluruh aktivitas organisasi.

f). Services, bahwa dalam intinya audit internal berusaha untuk membantu manajemen dalam melaksanakan fungsi pengendalian, oleh karena itu hasil pekerjaan audit internal pun harus diserahkan kepada manajemen.

g). To the Organization, ruang lingkup pelayanan audit internal ditujukan kepada seluruh bagian organisasi, termasuk semua personil perusahaan, dewan komisaris dan pemegang saham. Sedangkan pengertian audit internal menurut Arens et al., (2012) adalah sebagai berikut: Audit internal merupakan sebuah independensi, jaminan tujuan, dan memberikan konsultasi kegiatan yang dirancang 
untuk menambah nilai suatu organisasi dan meningkatkan operasi perusahaan.

Menurut Institute of Internal Auditor (IIA) dikutip oleh Sawyer (2005) adanya internal audit adalah bertujuan untuk menentukan:

a. Apakah informasi keuangan dan dan operasi telah akurat dan dapat diandalkan?

b. Apakah risiko yang dihadapi oleh perusahaan telah diidentifikasi dan diminimalisir?

c. Apakah peraturan eksternal serta kebijakan dan prosedur internal yang bisa diterima telah diikuti?

d. Apakah criteria operasi yang memuaskan telah dipenuhi?

e. Apakah sumber daya telah digunakan secara efisien dan ekonomis?

f. Apakah tujuan organisasi telah dicapai secara efektif?

Tujuan pemeriksanaan yang dilakukan oleh internal auditor adalah untuk membantu semua pimpinan perusahaan (manajemen) dalam melaksanakan tanggung jawabnya dengan memberikan analisa, penilaian, saran, dan komentar mengenai kegiatan yang diperiksanya. Untuk mencapai tujuan tersebut, internal auditor harus melakukan kegiatan-kegiatan berikut:

1). Menelaah dan menilai kebaikan, memadai tidaknya dan penerapan dari sistem pengendalian manajemen, pengendalian intern, dan pengendalian operasional lainnya serta mengembangkan pengendalian yang efektif dengan bia ya yang tidak terlalu mahal.

2). Memastikan ketaatan terhadap kebijakan, rencana dan prosedur-prosedur yang telah ditetapkan oleh manajemen.

3). Memastikan seberapa jauh harta perusahaan dipertanggungjawabkan dan dilindungi dari kemungkinan terjadinya segala bentuk pencurian, kecuranganm dan penyalahgunaan.

4). Memastikan bahwa pengelolan data yang dikembangkan dalam organisasi dapat dipercaya.
5). Menilai mutu pekerjaan setiap bagian dalam melaksanakan tugas yang diberikan oleh manajemen.

6). Menyarankan perbaikan-perbaikan operasional dalam rangka meningkatkan efisiensi dan efektivitas.

Tanggung jawab penting fungsi audit internal adalah memantau kinerja pengendalian internal dalam perusahaan. Pada waktu auditor berusaha memahami pengendalian internal, ia harus berusaha memahami fungsi audit internal untuk mengidentifikasi aktivitas audit internal yang relevan dengan perencanaan audit. Lingkup prosedur yang diperlukan untuk memahaminya bervariasi, tergantung atas sifat aktivitas audit internal tersebut. Tanggung jawab seorang audit internal menurut Komite SPAP Ikatan Akuntan Indonesia dalam Standar Profesi Akuntan Publik (2004) yaitu: Auditor internal bertanggung jawab untuk menyediakan jasa analisis dan evaluasi, memberikan keyakinan dan rekomendasi dan informasi lain kepada manajemen entitas dan bagian komisaris atau pihak lain yang setara wewenang dan tanggung jawabnya. Untuk memenuhi tanggung jawabnya tersebut auditor intern mempertahankan objektivitasnya yang berkaitan dengan aktivitas yang diauditnya.

Wewenang yang dapat ditetapkan bagi auditor internal antara lain:

a). Menyusun program audit internal secara menyeluruh atau semua aktifitas dalam perusahaan.

b). Menguji keandalan pengendalian manajemen.

c). Tanpa batasan untuk memasuki semua bagian perusahaan, meneliti catatan, pelaporan serta harta milik perusahaan.

Dalam program audit internal, untuk dapat melakukan audit yang sistematis dan terarah maka pada saat audit dimulai, audit intenal terlebih dahulu menyusun suatu perencanaan atau program audit yang akan dilakukan. Program audit ini dapat dipergunakan sebagai alat perencanaan dan pengawasan yang efektif atas pekerjaan audit secara keseluruhan. 
Dalam proses ERM, auditor internal harus mendapatkan bukti yang cukup dan tepat untuk menentukan bahwa tujuan kunci dari proses manajemen risiko telah tercapai dalam memberikan opini atas kecukupan proses manajemen risiko. Dalam mengumpulkan bukti-bukti tersebut, auditor internal mungkin mempertimbangkan prosedur audit berikut ini:

1). Melakukan riset dan review perkembangan, tren, dan informasi industri terkini terkait dengan usaha yang dilakukan oleh organisasi, serta sumber informasi lain yang sesuai untuk menentukan risiko dan eksposur yang dapat mempengaruhi organisasi beserta prosedur pengendalian yang relevan.

2). Me-review kebijakan perusahaan dan risalah rapat Dewan untuk menentukan strategi bisnis organisasi, filosofi dan metodologi manajemen risiko, selera risiko, serta penerimaan risiko.

3). Me-review laporan evaluasi risiko sebelumnya yang dikeluarkan oleh manajemen, auditor internal, auditor eksternal, dan/atau sumber lain.

4). Melakukan wawancara dengan manajemen lini dan manajemen senior untuk menentukan tujuan unit bisnis, risiko yang terkait, serta mitigasi risiko dan aktivitas pemantauan pengendalian manajemen.

5). Menyerap informasi untuk kemudian secara independen mengevaluasi efektivitas mitigasi risiko, pemantauan, dan komunikasi risiko beserta kegiatan pengendalian terkait.

6). Menilai ketepatan garis pelaporan untuk aktivitas pemantauan risiko.

7). Me-review kecukupan dan ketepatan waktu pelaporan hasil manajemen risiko.

8). Review kelengkapan analisis risiko yang dilakukan manajemen serta tindakan yang diambil untuk mengatasi isu yang diangkat oleh proses manajemen risiko, dan menyarankan perbaikan.

9). Menentukan efektivitas proses self-assessment yang dilakukan manajemen melalui pengamatan, tes langsung atas prosedur pengendalian dan pemantauan, pengujian keakuratan informasi yang digunakan dalam aktivitas pemantauan, serta teknik lainnya yang sesuai.

Me-review isu terkait risiko yang mungkin menunjukkan kelemahan dalam praktik manajemen risiko dan, jika perlu, diskusikan dengan manajemen senior dan Dewan. Jika auditor yakin bahwa manajemen telah menerima tingkat risiko yang tidak sesuai (atau yang dianggap tidak bisa diterima) dengan strategi dan kebijakan manajemen risiko organisasi, auditor harus mengacu pada standar 2600 dan pedoman audit internal lain terkait (PA 2120-1: Assessing the Adequacy of Risk Management Processes. Jan 1, 2009).

\section{Pengertian Komite Audit}

Komite Audit memiliki tugas terpisah dalam membantu Dewan Komisaris untuk memenuhi tanggung jawabnya dalam memberikan pengawasan secara menyeluruh. Secara umum, komite audit dibentuk untuk membantu dewan komisaris (dalam two tiers system) untuk mengawasi kinerja kegiatan pelaporan keuangan dan pelaksanaan audit, baik internal maupun eksternal di dalam perusahaan. Dan karenanya, untuk mempertahankan independensi, komite audit beranggotakan komisaris independen dan pihakpihak luar perusahaan yang terlepas dari kegiatan manajemen sehari-hari dan mempunyai tanggung jawab utama untuk membantu dewan komisaris dalam menjalankan tanggung jawabnya terutama dengan masalah yang berhu-bungan dengan kebijakan akuntansi perusahaan, pengawasan internal, dan system pelaporan keuangan. Komite audit yang bertanggung jawab untuk mengawasi laporan keuangan, mengawasi audit eksternal, dan mengamati sistem pengendalian internal (termasuk audit internal) dapat mengurangi sifat opportunistic manajemen yang melakukan manajemen laba (earnings management) dengan cara mengawasi laporan keuangan dan melakukan pengawasan pada audit eksternal. 
Peran komite audit adalah untuk mendukung fungsi audit internal, memastikan bahwa auditor internal memiliki status yang diperlukan dan sumber daya untuk tetap objektif (Bailey, 2007). Salah satu aspek yang cukup penting dalam keberhasilan komite audit dalam menjalankan tugasnya adalah masalah komunikasi. Oleh karena itu komite audit harus meningkatkan komunikasi dengan dewan komisaris, manajemen, internal auditor dan eksternal auditor. Adanya komunikasi yang lancar antara komite audit dengan berbagai pihak tersebut dapat menunjukkan eksistensi komite audit lebih efektif dan dapat meringankan tugas komisaris dalam mengawasi jalannya perusahaan.

\section{Enterprise Risk Management}

ERM didefinisikan oleh COSO (2004) sebagai sebuah proses yang dipengaruhi oleh dewan entitas direksi, manajemen dan personil lainnya, diterapkan dalam pengaturan strategi dan di seluruh perusahaan, yang dirancang untuk mengidentifikasi peristiwa potensial yang dapat mempengaruhi entitas, dan mengelola risiko berada dalam risiko, untuk memberikan yang wajar jaminan mengenai pencapaian tujuan entitas. ERM COSO menjelaskan bahwa manajemen risiko perusahaan memungkinkan pemimpin perusahaan untuk menangani ketidakpastian, risiko yang terkait dan peluang yang meningkatkan kapasitas untuk membangun nilai tambah. Nilai tambah ini akan semakin besar ketika pimpinan perusahaan menetapkan strategi dan tujuan untuk mencapai keseimbangan yang optimal antara pertumbuhan usaha dengan risiko yang ada.

Enterprise Risk Management (ERM) didefinisikan dengan sangat baik oleh Committee of Sponsoring Organizations of The Treadway Commission (COSO) dalam Enterprise Risk Management Integrated Framework (2004). COSO menginisiasi suatu proyek untuk mengembangkan suatu framework yang sehat secara konseptual. Framework ini mengintegrasikan prinsip, terminologi, dan pedoman implementasi praktis untuk mendukung program entitas dalam mengembangkan atau mem-benchmark proses Enterprise Risk Management yang mereka terapkan. Enterprise Risk Management didefinisikan sebagai berikut: "Enterprise Risk Management is a process, effected by an entity's board of directors, management and other personnel, applied in strategy setting and across the enterprise, designed to identify potential events that may affect the entity, and manage risks to be within its risk appetite, to provide reasonable assurance regarding the achievement of entity objectives".

Sebagai suatu proses, Enterprise Risk Management adalah sarana untuk mencapai tujuan, dan bukan tujuan itu sendiri. ERM bukan sekadar kebijakan, isian survei dan formulir, tetapi melibatkan orang di berbagai aras organisasi. Applied in strategy setting, diterapkan dalam penyusunan strategi, across the enterprise, bersifat menyeluruh di setiap tingkat dan unit organisasi, termasuk keharusan untuk memandang risiko tingkat entitas secara portofolio. Enterprise Risk Management dirancang untuk mengidentifikasi peristiwa-peristiwa potensial yang mempengaruhi entitas dan mengelola risiko agar senantiasa berada dalam risk appetite organisasi. Tujuannya adalah untuk memberikan re-Asonable Assurance (kepastian secara wajar) bagi manajemen dan pengurus perusahaan terkait dengan Achievement of Objectives, pencapaian tujuan, dalam satu atau beberapa kategori terpisah yang juga bisa bersifat tumpang tindih. Tidak ada entitas yang beroperasi dalam lingkungan yang bebas risiko dan Enterprise Risk Management tidak menciptakan lingkungan yang demikian. Akan tetapi, Enterprise Risk Management memungkinkan manajemen untuk beroperasi secara lebih efektif dalam lingkungan yang penuh dengan risiko. Enterprise Risk Management meningkatkan kemampuan organisasi untuk:

1). Menyelaraskan risk appetite dan strategi. Risk appetite adalah tingkat risiko, pada aras yang berbasis luas, yang dapat diterima oleh suatu perusahaan atau entitas dalam mengejar sasaran-sasarannya. Manajemen terlebih dahulu mempertimbangkan risk 
appetite entitas dalam mengevaluasi alternatif strategik, kemudian dalam menetapkan objektif yang diselaraskan dengan strategi yang telah ditetapkan dan dalam mengembangkan mekanisme untuk mengelola risiko-risiko terkait.

2). Mengaitkan antara pertumbuhan, risiko dan return Entitas menerima risiko sebagai bagian dari penciptaan dan pemeliharaan nilai, dan mendapatkan return sesuai risiko yang diambilnya.

Enterprise Risk Management meningkatkan kemampuan entitas dalam mengidentifikasi dan menelaah (assess) risiko, menetapkan tingkat risiko yang dapat diterima, relatif terhadap objektif pertumbuhan dan return yang dikehendaki.

3). Meningkatkan kualitas keputusan dalam merespon risiko.

Enterprise Risk Management mempertajam ketepatan dalam mengidentifikasi dan memilih alternatif respon terhadap risiko menghindari (avoid), mereduksi (reduce), membagi (share) dan menerima (accept) risiko. Enterprise Risk Management memberikan manajemen metodologi dan teknik untuk membuat keputusan-keputusan tersebut.

4). Meminimalisasi kejutan dan kerugian operasional.

Entitas akan memiliki kapabilitas yang lebih tinggi untuk mengidentifikasi peristiwa-peristiwa potensial, menelaah risiko dan menetapkan respon. Dengan demikian entitas dapat mereduksi kemungkinan terjadinya kejutan atau kerugian.

5). Mengidentifikasi dan mengelola risiko secara menyeluruh (crossenterprise risks).

Setiap entitas menghadapi tidak terhitung risiko yang mempengaruhi berbagai bagian da-lam organisasi. Manajemen bukan hanya harus mengelola risiko-risiko tersebut satu persatu, tetapi juga harus memahami keterkaitan dampak risiko-risiko tersebut.

6). Memberikan respon terpadu terhadap risiko berganda.

Proses bisnis mengandung di dalamnya banyak risiko inheren, dan Enterprise Risk Management memungkinkan manajemen memberikan solusi terpadu untuk mengelola risiko-risiko tersebut.

7). Menangkap peluang.

Manajemen bukan hanya harus memperhatikan risiko tetapi juga peristiwa peristiwa potensial. Dengan mempertimbangkan rangkaian peristiwa terkait secara menyeluruh, manajemen dapat memiliki pemahaman tentang peristiwa-peristiwa yang menjanjikan peluang.

8). Merasionalisasi kapital.

Informasi yang lebih handal terkait dengan total risiko entitas memungkinkan Direktur dan Komisaris serta manajemen perusahaan menelaah secara lebih efektif kebutuhan modal perusahaan secara menyeluruh dan meningkatkan ketepatan alokasi modal. Enterprise Risk Management bukanlah tujuan, melainkan sarana yang penting. ERM tidak berjalan terpisah dalam suatu entitas, melainkan lebih merupakan enabler proses manajemen. Enterprise Risk Management saling terkait dengan Corporate Governance dengan memberikan informasi kepada pengurus perusahaan (Direksi dan Komisaris) mengenai risiko-risiko yang paling signifikan dan bagaimana risiko-risiko tersebut dikelola. ERM saling terkait dengan manajemen kinerja dengan memberikan ukuranukuran berbobot risiko (risk adjusted measures), dan dengan pengendalian internal, yang merupakan bagian tidak terpisahkan dari Enterprise Risk Management.

9). Kebutuhan akan kompetensi di bidang ERM bagi Direktur dan Komisaris.

Sejarah berulangkali memperlihatkan bagaimana hal-hal yang buruk dapat dan telah menimpa perusahaan-perusahaan yang baik. Dalam bagian ini akan dibahas betapa pentingnya manajemen risiko bagi Direksi dan Komisaris sehingga kompetensi dalam bidang Enterprise Risk Management kini telah menjadi suatu keharusan. Bencana-bencana korporasi dapat muncul dalam berbagai bentuk dan dapat menimpa perusahaan dan industri apapun. Disamping kerugian finansial murni, pengelolaan risiko dapat berakibat rusaknya reputasi perusahaan, atau kemunduran perjalanan karir para eksekutifnya. Eskalasi kerusakan dapat berlangsung 
dengan cepat hingga perusahaan yang tadinya sehat tiba-tiba menghadapi kebangkrutan; seringkali peristiwa kerusakan ini dapat menggoncangkan pondasi industri dan pasar dengan parah.

Posisi pada audit internal dalam ERM (IIA, 2004b) diuraikan tiga kategori peran ERM:

1). Peran inti audit internal dalam ERM adalah kegiatan yang berhubungan dengan layanan pemastian yang meliputi:

a). Pemberian keyakinan pada desain dan efektivitas proses manajemen risiko.

b). Pemberian keyakinan bahwa risiko dievaluasi dengan benar.

c). Mengevaluasi proses manajemen risiko.

d). Mengevaluasi pelaporan mengenai status dari risiko-risiko kunci dan pengendaliannya.

e). Meninjau pengelolaan risiko-risiko kunci, termasuk efektivitas dari pengendalian dan respon lain terhadap risiko-risiko tersebut.

2). Peran tambahan lain yang boleh dilaksanakan dalam layanan konsultasi dengan dibarengi pengamanan independensi dan objektivitas yang cukup, antara lain:

a). Memulai pembentukan ERM dalam organisasi.

b). Mengembangkan strategi manajemen risiko bagi persetujuan dewan.

c). Memfasilitasi identifikasi dan evaluasi risiko.

d). Pelatihan manajemen tentang merespon risiko.

e). Mengoordinasikan kegiatan ERM.

f). Mengonsolidasi laporan mengenai risiko.

g). Memelihara dan mengembangkan kerangka ERM.

3). Peran dalam ERM yang tidak boleh dilakukan auditor internal adalah:

a). Mengatur minat risiko (risk appetite).

b). Menerapkan proses manajemen risiko.

c). Menjamin manajemen risiko. d). Membuat keputusan pada respon risiko.

e). Menerapkan respon dan manajemen risiko atas nama manajemen.

f). Akuntabilitas manajemen risiko.

Dibandingkan dengan pendahulunya, ERM COSO menambahkan konsep baru yaitu event management. Konsep ini dianggap sebagai perubahan penting terhadap COSO I yang sangat baik untuk diterapkan pada proses atau kegiatan berulang (repetitive). Namun justru risiko timbul jika terjadi hal di luar dari proses atau kegiatan berulang tadi. Kejadian khusus atau special event ini dapat memberikan dampak negatif, positif, atau keduanya. Kejadian dengan dampak negatif menimbulkan kerugian (risiko) yang dapat mengurangi atau menghambat peningkatan nilai tambah. Kejadian dengan dampak positif sebaliknya, dapat menutupi dampak negatif atau menyajikan peluang baru. Peluang itu sendiri merupakan kemungkinan yang diharapkan akan terjadi dan secara positif mempengaruhi pencapaian tujuan organisasi serta mendukung peningkatan nilai tambah. Pimpinan mengembalikan kembali peluang tersebut kepada jalur strategi yang telah direncanakan, kemudian merumuskan rencana untuk merealisasikannya.

COSO ERM memiliki delapan Komponen kategori, yaitu:

1. Lingkungan Internal.

2. Menetapkan Tujuan.

3. Event Identifikasi.

4. Penilaian Risiko.

5. Risiko Respon.

6. Kegiatan Pengendalian.

7. Informasi dan Komunikasi.

8. Pemantauan.

Sedangkan tujuan komponen COSO ERM adalah:

a). Strategi; tinggi tingkat tujuan, selaras dengan dan mendukung misi organisasi.

b). Operasi; penggunaan yang efektif dan efisien sumber daya.

c). Pelaporan Keuangan; keandalan pelaporan operasional dan keuangan.

d). Kepatuhan; kepatuhan terhadap hukum dan peraturan yang berlaku. 
Hasil riset George Allayannis dan James Watson (1990-1995) dari Universitas Virginia menyimpulkan bahwa manajemen risiko akan meningkatkan nilai perusahaan sekaligus mendukung pertumbuhan ekonomi dengan menurunkan biaya modal dan mengurangi ketidakpastian aktivitas sosial.

\section{Penelitian Terdahulu}

Studi yang dilakukan oleh Fraser dan Henry (2007) di UK menemukan bahwa audit internal dapat terlibat dalam ERM. Penelitian ini terdiri dari wawancara dengan direktur keuangan, komite audit, auditor internal dan risiko direksi dari lima perusahaan yang terdaftar, serta empat mitra dari perusahaan audit (Big Four). Para penulis juga menemukan bukti auditor internal memiliki tanggung jawab untuk praktik ERM. Secara umum, studi ini menunjukkan bahwa auditor internal, dalam beberapa kasus, terlibat da-

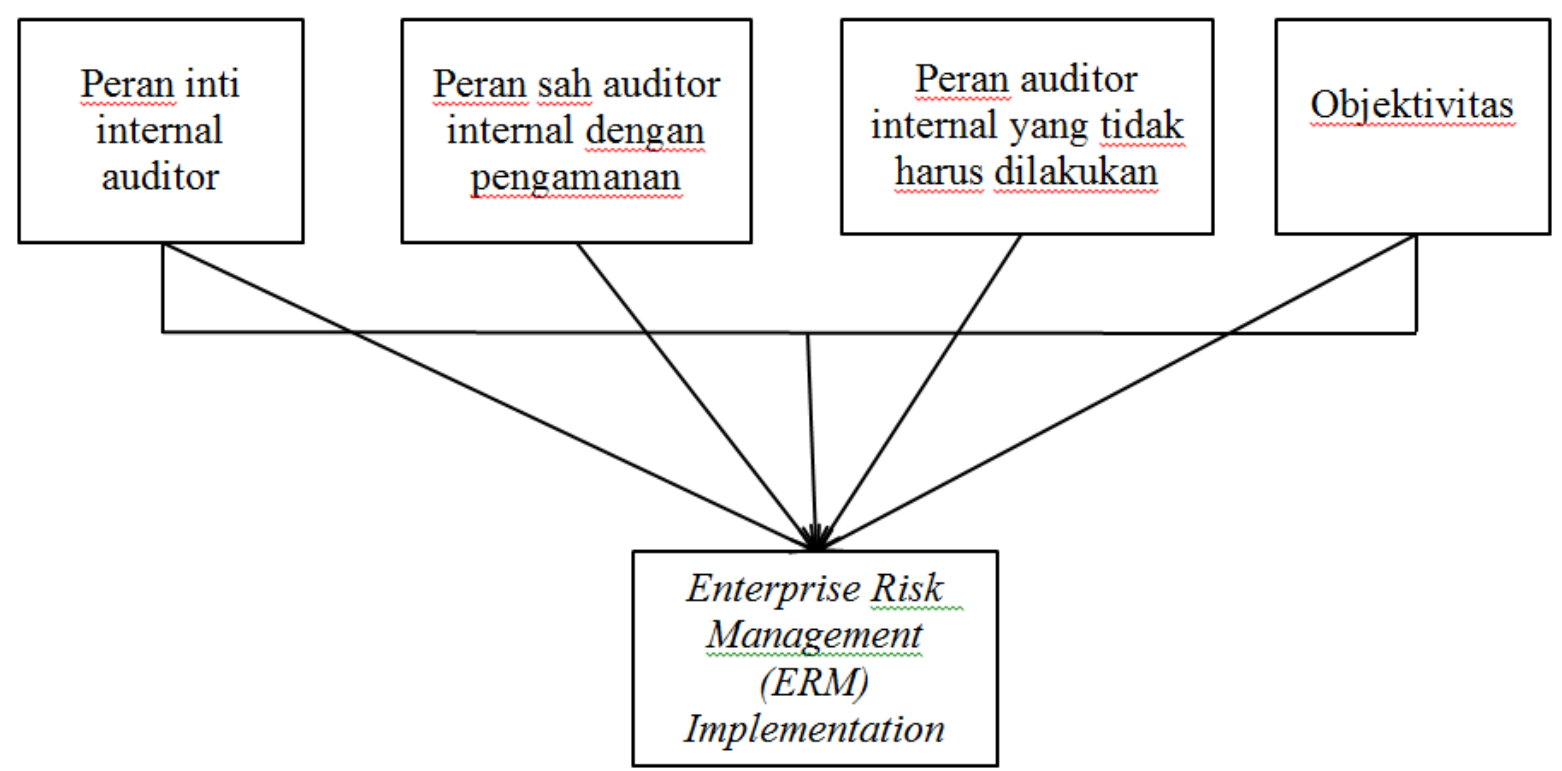

Gambar 1. Kerangka Pemikiran.

\section{Hipotesis Penelitian}

Peran auditor internal dalam manajemen risiko perusahaan sudah diatur dalam ERM Roles (IIA, 2004b). Dalam peran-peran yang sudah diatur tersebut, terdapat beberapa keterlibatan yang mungkin menimbulkan ancaman dalam objektifitas auditor internal. Manajemen risiko perusahaan menimbulkan ancaman yang signifikan bagi objektifitas da- lam kegiatan ERM yang telah dianggap cocok oleh IIA, sehingga terdapat sinyal risiko tinggi untuk kehilangan objektivitas auditor internal.

Penelitian lainnya, de Zwaan, dkk (2009) melakukan penelitian yang menunjukkan internal auditor yang memiliki keterlibatan tinggi kurang bersedia melaporkan kerusakan prosedur ERM dan ditemukan juga bahwa tidak ada pengaruh karakteristik hubungan yang kuat antara internal auditor dan komite auditor akan mempengaruhi kesediaan untuk melaporkan kerusakan prosedur ERM. Perbedaan penelitian yang dilakukan dengan penelitian terdahulu adalah bagaimana cara data diperoleh. Penelitian yang dilakukan menggunakan quasieksperimental sementara penelitian terdahulu menggunakan true eksperimental. Metode tersebut digunakan dengan menyesuaikan dengan kondisi lapangan tempat data diperoleh. 
Penelitian dari Gul dan Subramaniam (1994) menyediakan beberapa dukungan empiris untuk kemampuan auditor internal untuk menahan tekanan manajemen dalam situasi ketika adanya sebuah komite audit. Sebuah baris pelaporan langsung dengan komite audit dianggap untuk meningkatkan status audit internal (Adamec et al., 2005) dan untuk menghilangkan kemungkinan ancaman tekanan sosial ketika audit internal diperlukan untuk melaporkan kepada manajemen (Blue Ribbon Komite, 1999; Cohen et al., 2004). Berdasarkan pembahasan di atas, auditor internal kemungkinan akan menahan tekanan dari manajer lain untuk kompromi objektivitas ketika mereka memiliki hubungan yang kuat dan dekat dengan komite audit. Oleh karena itu, dalam situasi di mana auditor internal memiliki keterlibatan rendah pada manajemen risiko perusahaan, kami berharap bahwa mereka akan lebih bersedia untuk melaporkan gangguan dalam prosedur berisiko yang melibatkan rekan-rekan mereka ketika hubungan mereka kuat dengan komite audit. Skenario kedua melibatkan pengakuan kelemahan dalam kinerja sendiri. Kami berharap bahwa auditor internal enggan untuk melaporkan rincian prosedur risiko yang secara pribadi mereka bertanggung jawab, karena ini dapat berdampak negatif terhadap reputasi dan evaluasi kinerja mereka (Stefaniak dan Robertson, 2010; Donnelly et al., 2003; Larrick, 1993; Messier dan Quilliam, 1992; McNair, 19-91). Namun, hubungan yang erat dengan komite audit dapat memberikan auditor internal keyakinan lebih besar bahwa dia akan diperlakukan secara adil oleh komite audit karena kepercayaan yang telah dibangun dari waktu ke waktu. Oleh karena itu, kami berpendapat bahwa auditor internal akan lebih bersedia untuk bertanggung jawab melaporkan rincian dalam prosedur risiko ketika mereka memiliki hubungan erat dengan komite audit, tetapi kemauan untuk menyediakan laporan tidak akan sekuat seperti situasi di mana mereka tidak bertanggung jawab atas rincian tersebut. Oleh karena itu, untuk memprediksi efek interaksi keterlibatan auditor internal dalam manajemen risiko perusahaan dan hubungannya dengan komite audit, penelitian diarahkan pada hipotesis yaitu:

H.1 : Peran Inti Internal Audit mempunyai pengaruh dalam pelaksanaan Enterprise Risk Management (ERM) berupa pelaporan kerusakan prosedur Risiko.

H.2 : Peran sah Intenal audit dengan safeguard mempunyai pengaruh dalam pelaksanaan Enterprise Risk Management (ERM) berupa pelaporan kerusakan prosedur Risiko.

H.3 : Peran yang tidak harus dilakukan oleh Internal Audit mempunyai pengaruh dalam pelaksanaan Enterprise Risk Management (ERM) berupa pelaporan kerusakan prosedur Risiko.

H.4 : Objectivitas Internal Audit mempunyai pengaruh dalam pelaksanaan Enterprise Risk Management (ERM) berupa pelaporan kerusakan prosedur Risiko.

H.5 : Peran inti Intenal audit, Peran sah internal audit dengan safeguard, Peran yang tidak harus dilakukan, dan Objectivitas Internal Audit berpengaruh secara bersamaan terhadap pelaksanaan Enterprise Risk Management (ER$\mathrm{M})$ berupa pelaporan kerusakan prosedur Risiko.

\section{Metode Penelitian}

\section{Pemilihan dan Pengumpulan Data}

Penelitian ini dilaksanakan dengan mengambil data dari kuisioner yang disebarkan pada Internal Audit yang beroperasional di Perbankan dan Perusahaan swasta, dalam hal ini penelitian mengambil Internal Auditor pada satu Bank daerah dan satu perusahaan manufaktur, serta salah satu Kantor Akuntan Publik (KAP) yang ada di propinsi Riau.

Populasi dalam penelitian ini adalah para auditor internal beserta komite audit bekerja di perusahaan-perusahaan baik itu manufaktur, jasa keuangan. Alasan penentuan perusahaan tersebut adalah dikarenakan peneliti ingin mengetahui bagaimana internal audit terlibat dalam pelaksanaan ERM pada 
entitas tersebut. Perusahaan tersebut. Sampel adalah bagian dari populasi (elemen-elemen populasi) yang dinilai dapat mewakili karakteristiknya. Penentuan sampel pada penelitian ini dilakukan dengan metode convenience sampling. Penentuan sample menggunakan metode convenience sampling karena informasi mengenai keberadaan auditor internal dalam perusahaan tidak diketahui secara pasti. Oleh karena itu, sampel yang dipakai oleh peneliti adalah auditor internal pada perusahaan swasta dan pada Perbankan dalam hal ini auditor internal pada bank daerah. Ditargetkan pada penelitian ini total Internal Auditor yang akan dapat memberikan respon dari kuisioner adalah melebihi dari 30 responden dengan tujuan jawaban dari responden dapat dianalisa dan hasil penelitian tidak bias, sehingga dapat diberikan kesimpulan atas analisa hasil penelitian tersebut.

\section{Definisi Operasional Variabel Penelitian}

Variabel adalah apa pun yang dapat membedakan atau membawa variasi pada nilai (Sekaran, 2003). Dalam penelitian ini melibatkan dua variabel, yaitu variabel dependen dan variabel independen.

\section{Variabel Dependen (Terikat)}

Menurut Sugiyono (2007:4), "Variabel dependen merupakan variabel yang dipengaruhi atau yang menjadi akibat karena adanya variabel bebas”. Variabel dependen dalam penelitian ini adalah Pelaksanaan Enterprise Risk Management yaitu pelaporan kerusakan prosedur risiko.

Pelaksanaan Enterprise Risk Management yaitu:

1. Pelaporan KesalahanProsedur Risiko.

Dalam pelaksanaannya, dari setiap proses yang terdapat dalam manajemen risiko perusahaan akan menghasilkan sebuah laporan tentang bagaimana proses dalam manajemen risiko perusahaan itu telah berjalan. Setiap proses dalam manajemen risiko itu mempunyai prosedur masing-masing seperti yang sudah ditetapkan. Prosedur tersebut sering disebut prosedur risiko. Prosedur risiko itu akan dilaksanakan lalu kemudian dibuat laporan agar dapat diketahui apakah semua yang telah dilakukan selama ini sesuai prosedur atau tidak. Terkadang terjadi kesalahan dalam prosedur risiko tersebut namun tidak disebutkan dalam pelaporan. Pelaporan kesalahan prosedur ini dapat dilihat dari bagaimana status manajemen risiko pada perusahaan tersebut apakah sudah berjalan dengan lancar dan baik atau belum.

2. Pelaporan kerusakan risiko prosedur.

- Y1.1 Kondisi penerapan ERM pada perusahaan.

- Y1.2 Pentingnya ERM pada perusahaan.

- Y1.3 Implementasi ERM dalam perusahaan.

- Y1.4 Penggunaan ERM dan implementasi yang sudah baik.

- Y1.5 Adanya keinginan untuk menggunakan ERM.

\section{Variabel Independen}

Variabel independen merupakan variabel yang menjelaskan atau mempengaruhi variabel lain. Variabel independen dalam penelitian ini yaitu tingkat keterlibatan auditor internal yang tinggi dalam ERM (yang dimanipulasi sebagai tinggi atau rendah) dan karakteristik hubungan yang kuat antara auditor internal dan komite audit.

Tingkat Keterlibatan Auditor Internal yang Tinggi Dalam ERM $\rightarrow$ Terdapat pada Variabel independen X1, X2, X3.

- Konsep Peran Auditor Internal dalam ERM (IIA,2004a,b).

- Menggunakan 18 pertanyaan indikator yang diadopsi dari Peran Auditor Internal dalam ERM (IIA,2004a,b) dengan penyesuaian. Skala pengukuran yang digunakan adalah skala likert dengan jumlah skor antara 1 sampai dengan 5 (menyatakan sangat tidak setuju sampai sangat setuju).

\section{Peran Inti Internal Audit}

Dalam penelitian ini menggunakan 
variabel Peran inti internal audit dalam melaksanakan Enterprise Risk Management dalam aktivitasnya. Dalam hal ini akan diajukan pertanyaan sebagai berikut:

X1: Core internal auditing roles in ERM.

X1.1: Internal Audit memberikan jaminan atas proses manajemen Risiko (Giving assurance on risk management processes).

X1.2: Internal Audit memberikan jaminan bahwa Risiko yang terjadi di operasional perusahaan dievaluasi dengan benar. (Giving assurance that risks are correctly evaluated).

X1.3: Internal Audit Mengevaluasi manajemen Risiko (Evaluating risk management processes).

X1.4: Internal Audit mengevaluasi pelaporan Risiko (Evaluating the reporting of risks).

X2: Legitimate internal auditing roles with safeguards

X2.1: Internal Audit Meninjau pengelolaan risiko utama (Reviewing the management of key risks).

X2.2: Memfasilitasi identifikasi dan evaluasi risiko (Facilitating $i$ dentification and evaluation of risks).

X2.3: Internal Audit harus melakukan pembinaan manajemen dalam merespon risiko (Coaching management in responding to risks).

X2.4: Mengkonsolidasikan pelaporan pada risiko (Consolidating the reporting on risks).

X2.5: Mengkoordinasikan kegiatan ERM (Coordinating ERM activities).

X2.6: Mengkonsolidasikan pelaporan pada risiko (Consolidating the reporting on risks).

X2.7: Mempertahankan dan mengembangkan kerangka ERM (Maintaining and developing the ERM framework).
X2.8: Memperjuangkan pembentukan ERM (Championing establishment of ERM).

X2.9: Mengembangkan strategi manajemen risiko untuk memperoleh approval Direksi (Developing risk management strategy for board Approval)

X3: Roles internal auditing should not undertake (Peran audit internal yang tidak harus dilakukan ).

X3.1: Mengatur risk appetite.

X3.2: Internal Audit harus memeastikan adanya pelaksanaan proses manajemen risiko.

X3.3: Mengambil keputusan atas tanggapan risiko.

X3.4: Menerapkan tanggapan risiko atas nama manajemen.

X3.5: Akuntabilitas manajemen risiko.

\section{Jenis dan Sumber Data}

Jenis data yang digunakan dalam penelitian ini adalah data primer. Data primer merupakan sumber data penelitian yang diperoleh secara langsung dari sumber asli, tidak melalui perantara. Data primer yang digunakan berupa data subyek (self report data) yang berupa opini dan karakteristik dari responden. Data primer dalam penelitian ini berupa:

1. Karakteristik responden yaitu auditor internal pada perusahaan yang memiliki pengalaman audit internal antara lima dan 15 tahun.

2. Tanggapan atau opini responden atas keterlibatan audit internal dalam ERM (Manajemen Risiko Perusahaan) dan kekuatan hubungan antara komite audit atau audit internal.

Sumber data adalah para auditor internal yang bekerja di perusahaan perusahaan di Propinsi Riau.

\section{Metode Pengumpulan Data}

Metode pengumpulan data yang dilakukan dalam penelitian ini adalah 
menggunakan metode penyebaran kuisioner yang telah disusun secara terstruktur, dimana sejumlah pertanyaan tertulis disampaikan pada responden untuk ditanggapi sesuai dengan kondisi yang dialami oleh responden yang bersangkutan. Pertanyaan berkaitan dengan pengalaman responden serta opini atau tanggapan terhadap keterlibatan audit internal dalam ERM serta kekuatan hubungan komite audit dengan audit internal dari para auditor internal di perusahaanperusahaan yang ada di Propinsi Riau, dan juga untuk mengetahui seberapa besar ERM sudah diterapkan di perusahaan- perusahaan yang ada di Propinsi Riau. Dalam pengukurannya, setiap responden diminta pendapatnya mengenai suatu pertanyaan, dengan skala penilaian dari 1 sampai dengan 5. Skala pengukuran persepsi responden (skala Likert 1 s.d 5) Sangat rendah sampai $\begin{array}{llllll}\text { Sangat tinggi } & 1 & 2 & 3 & 4 & 5 .\end{array}$

\section{Metode Analisis Data}

Penelitian ini menggunakan metode kuantitatif, diharapkan akan didapatkan hasil pengukuran yang lebih akurat tentang respon yang diberikan oleh responden, sehingga data yang diberikan oleh responden, sehingga data yang berbentuk angka tersebut dapat diolah dengan menggunakan metode statistik.

\section{a. Uji Reliabilitas}

Reliabilitas sebenarnya adalah alat untuk mengukur suatu kuesioner yang merupakan indikator dari variabel atau konstruk. Suatu kuesioner dikatakan reliabel atau handal jika jawaban seseorang terhadap pertanyaan adalah konsisten atau stabil dari waktu ke waktu (Ghozali, 2011).

b. Uji Validitas

Uji validitas digunakan untuk mengukur sah atau valid tidaknya suatu kuesioner. Suatu kuesioner dikatakan valid jika pertanyaan pada kuesioner mampu untuk mengungkapkan sesuatu yang akan diukur oleh kuesioner tersebut (Ghozali, 2011).

c. Uji Beda t-test

Uji beda t-test digunakan untuk menentukan apakah dua sample yang tidak berhu- bungan memiliki nilai rata-rata yang berbeda. Uji ini bertujuan untuk membandingkan rata-rata dua grup yang tidak berhubungan satu sama lain. Apakah kedua group tersebut mempunyai nilai rata-rata yang sama atau tidak sama secara signifikan (Ghozali, 2011).

\section{Analisis Statistik Deskriptif}

Diskripsi jawaban responden di sini dimaksudkan untuk menganalisis data berdasarkan atas hasil yang diperoleh dari jawaban responden terhadap masing-masing indikator pengukur variabel.

\section{Pengujian Hipotesis}

Pengujian hipotesis dalam penelitian ini dilakukan dengan tahapan sebagai berikut:

a. Uji Normalitas

Uji normalitas dilakukan untuk menentukan teknik analisis data yang paling tepat ntuk membuktikan hipotesis. Pengujian normalitas data dilakukan dengan menggunakan uji Kolmogorov Smirnov pada masing-masing kelompok.

\section{Hasil dan Pembahasan}

\section{Hasil Penelitian}

\section{Deskripsi Data Penelitian}

Penelitian ini menggunakan data primer berupa kuesioner, dengan memberikan pertanyaan sesuai dengan Keterlibatan Auditor dalam menerapkan Enterprise Risk Management (ERM). Responden yang menjadi objek penelitian adalah para Auditor Internal yang bekerja pada jenis perusahaan manufaktur. Jumlah Auditor Internal yang digunakan pada responden penelitian ini berjumlah 37 orang dengan berbagai jenis Auditor. Pengolahan data berdasarkan hasil jawaban dari kuisioner yang diberikan ke responden.

\section{Uji Asumsi Klasik}

Sebelum melakukan interpretasi terhadap 
hasil regresi, terlebih dahulu dilakukan pengujian terhadap asumsi-asumsi klasik agar hasil tersebut layak digunakan. Pengujian ini diperlukan agar model regresi menjadi suatu model yang lebih representatif. Analisis data uji asumsi klasik dalam penelitian ini antara lain melalui uji normalitas, multikolinearitas, autokorelasi dan heteroskedastisitas.

\section{Uji Normalitas}

Uji normalitas bertujuan untuk menguji apakah dalam model regresi, variabel pengganggu atau residual memiliki distribusi normal. Untuk menguji apakah residual berdistribusi normal atau tidak terdapat dua cara yaitu dengan analisis grafik dan uji statistik.

\section{a). Analisis Grafik}

Uji normalitas dengan analisis grafik dilakukan dengan metode grafik histogram dan Probability Plot (P-Plot). Selengkapnya mengenai hasil uji normalitas penelitian ini dapat dilihat pada Gambar. 2 berikut ini:

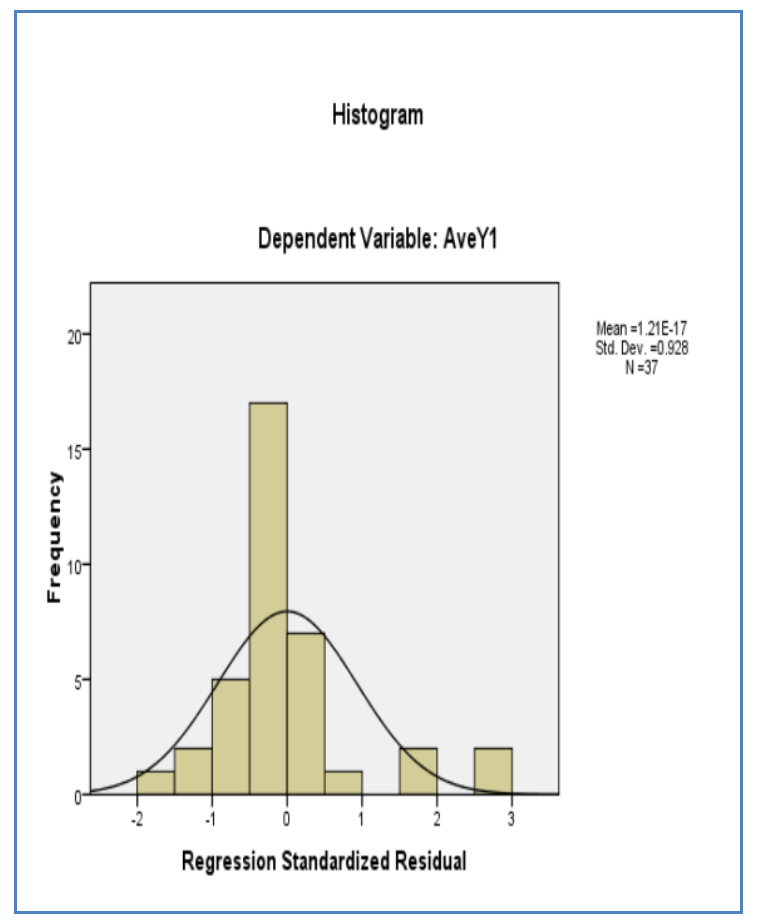

Gambar 2. Hasil Uji Normalitas dengan Histogram.

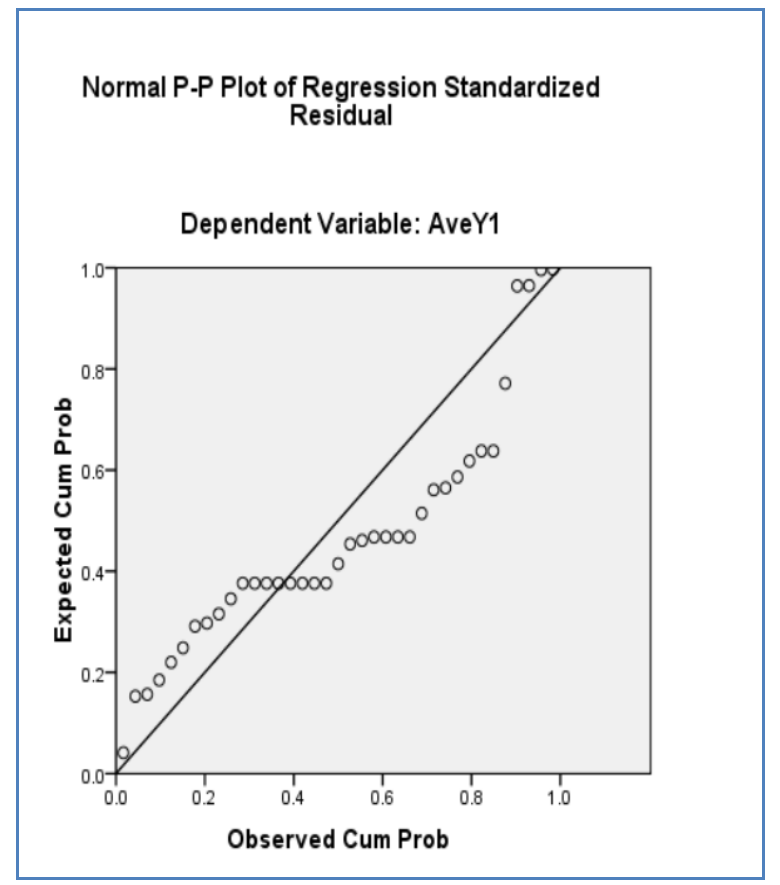

Gambar 3. Hasil Uji Normalitas dengan $P$ Plot.

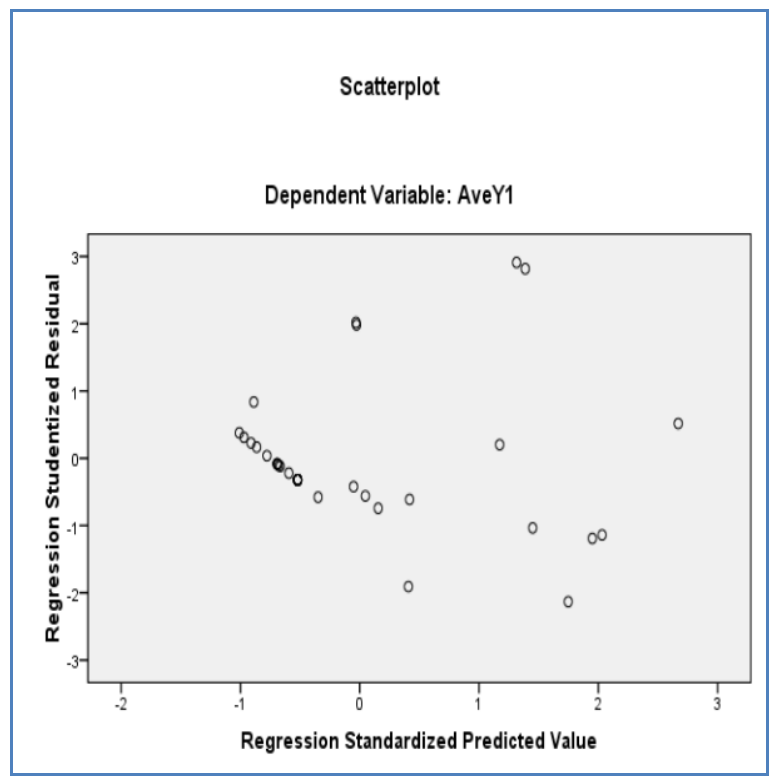

Gambar 4. Hasil Uji Normalitas dengan Scatter plot.

Dengan melihat tampilan pada grafik histogram dalam gambar 1 memberikan pola distribusi yang mendekati normal, sedangkan pada gambar grafik normal probability plot menunjukkan titik-titik menyebar disekitar garis diagonal dan penyebarannya mengikuti arah garis diagonal. Maka dapat disimpulkan bahwa model regresi dalam penelitian ini telah memenuhi asumsi normalitas. 


\section{Uji Statistik}

\section{Uji Multikoloneritas}

Uji multikolinearitas bertujuan untuk menguji apakah dalam model regresi ditemukan adanya korelasi antar variabel bebas (independen). Model regresi yang baik seharusnya tidak terjadi korelasi di antara variabel independen. Multikolinearitas dapat dilihat dari perhitungan nilai tolerance serta Variance Inflation Factor (VIF). Suatu model regresi disimpulkan tidak ada masalah multikolinearitas adalah apabila memiliki nilai tolerance lebih besar dari 0,10 dan nilai Variance Inflation Factor (VIF) lebih kecil dari 10 (Ghozali, 2011:106). Selengkapnya hasil pengujian asumsi klasik multikolinearitas dapat dilihat pada tabel 1 berikut ini:

Tabel 1. Tabel Uji Multikolinearitas.

\begin{tabular}{|c|c|c|c|}
\hline \multirow[t]{2}{*}{ Model } & & \multicolumn{2}{|c|}{$\begin{array}{c}\text { Collinearity } \\
\text { Statistics }\end{array}$} \\
\hline & & Tolerance & VIF \\
\hline \multirow[t]{6}{*}{1} & (Constant) & & \\
\hline & AVEX1 & .356 & 2.810 \\
\hline & AVEX2 & .487 & 2.055 \\
\hline & Avex3 & .691 & 1.447 \\
\hline & AveX4 & .315 & 3.172 \\
\hline & AveX5 & .259 & 3.860 \\
\hline
\end{tabular}

Pada tabel diatas, terlihat bahwa nilai VIF X1, X2, X3, X4, dan X5 lebih kecil dari 10 , maka masing-masing variabel tidak terdapat multikolinearitas.

\section{Koefisien determinasi}

Uji koefisien determinasi (R2) pada intinya adalah untuk mengetahui seberapa jauh kemampuan model dalam menerangkan variasi variabel dependen. Nilai koefisien determinasi (R2) adalah antara 0 (nol) dan 1 (satu). Nilai koefisien determinasi (R2) yang kecil berarti kemampuan variabel-variabel independen dalam menjelaskan variasi variabel dependen amat terbatas. Nilai yang mendekati satu berarti variabel-variabel independen memberikan hampir semua informasi yang dibutuhkan untuk memprediksi variasi variabel dependen (Ghozali, 2011: 97).

Pada model regresi berganda penggunaan nilai Adjusted R2 lebih baik dibandingkan dengan hanya melihat pada nilai koefisien determinasi (R2) untuk mengetahui seberapa jauh kemampuan model dalam menerangkan variasi variabel dependen. Hal ini disebabkan penggunaan koefisien determinasi (R2) memiliki kelemahan mendasar yaitu bias terhadap jumlah variabel independen yang dimasukkan ke dalam model. Hasil uji koefisien determinasi dapat dilihat pada tabel 2.

Tabel 2. Uji Determinasi.

\begin{tabular}{cccc}
\hline Model & $\mathbf{R}$ & $\boldsymbol{R}$ Square & Adjusted $\boldsymbol{R}$ Square \\
\hline 1 & $.835^{\mathrm{a}}$ & .697 & .648 \\
\hline
\end{tabular}

a. Predictors: (Constant), AveX5, Avex3, AVEX2, AVEX1, AveX4.

b. Dependent Variable: AveY1.

Dari tabel 2 di atas menunjukkan bahwa nilai Adjusted R2 sebesar 0,697 berarti bahwa sebesar $69,7 \%$ variasi variabel dependen yaitu Y1: Pelaporan Kerusakan Risiko Prosedur dapat dijelaskan oleh variabel independen yaitu: a) X1; Peran inti IA dalam ERM, b) X2; Peran IA yang legitimate, c)
X3; Roles IA tidak harus melakukan, d) X4; Hubungan antar Komite Audit dan Audit Internal yang Kuat, e) X5; Hubungan antar Komite Audit yang lemah dalam penelitian ini. Hal ini menandakan masih rendah atau lemahnya kemampuan variabel independen dalam menjelaskan variabel dependen, 
sedangkan sisanya yaitu sebesar 30,3\% dijelaskan oleh variabel lain yang tidak dimasukkan dalam penelitian ini.

\section{Pengujian Hipotesis}

Pengujian hipotesis dalam penelitian ini menggunakan analisis regresi linier sederhana dan analisis regresi linier berganda. Teknik analisis regresi linier sederhana digunakan untuk menguji hipotesis pertama. Hal ini dilakukan untuk mengetahui pengaruh variabel independen terhadap variabel dependen secara parsial. Hal ini bertujuan untuk mengetahui pengaruh variabel independen berupa leverage terhadap manajemen variabel dependen. Teknik analisis tersebut dilakukan dengan menggunakan program SPSS versi 23.

\section{Uji Signifikansi Regresi Berganda (Uji F)}

Pengujian signifikansi regresi berganda dilakukan dengan cara membandingkan $\mathrm{F}$ hitung dengan $\mathrm{F}$ tabel atau dapat pula dilakukan dengan membandingkan nilai probabilitas signifikansi dengan tingkat signifikansi yang telah ditentukan, yaitu sebesar 0,05 . Berdasarkan gambar, diperoleh hasil bahwa Nilai probabilitas signifikansi sebesar 0,000 juga menunjukkan nilai yang lebih kecil dari pada tingkat signifikansi yang telah ditentukan yaitu $0,05(0,00<0,05)$. Berdasarkan hasil uji hipotesis tersebut, dapat dikatakan bahwa hipotesis yang berbunyi Keterlibatan Internal Auditor dalam pelaksanaan ERM. Uji statistik F pada dasarnya digunakan untuk mengetahui apakah semua variabel independen/bebas yang dimasukkan dalam model mempunyai pengaruh secara bersama-sama terhadap variabel dependen/ terikat (Ghozali, 2011:98). Uji statistik F dalam penelitian ini dilakukan dengan melihat nilai signifikansi (sig) pada uji ANOVA. Selengkapnya mengenai hasil uji statistik $\mathrm{F}$ penelitian ini dapat dilihat pada tabel 3 berikut ini:

Tabel 3. Uji-F

\begin{tabular}{llrrrrr}
\hline \multicolumn{8}{c}{ ANOVA $^{\text {a }}$} \\
& Model & Sum of Squares & df & Mean Square & F & \multicolumn{1}{c}{ Sig. } \\
\hline 1 & Regression & 8.781 & 5 & 1.756 & 14.253 & $.000^{\mathrm{b}}$ \\
& Residual & 3.820 & 31 & .123 & & \\
& Total & 12.601 & 36 & & & \\
\hline
\end{tabular}

a. Dependent Variable: AveY1.

b. Predictors: (Constant), AveX5, Avex3, AVEX2, AVEX1, AveX4.

Dari tabel 3 di atas menunjukkan nilai $\mathrm{F}$ hitung sebesar 14,253 dengan nilai signifikansi sebesar 0,000. Hal ini menandakan bahwa model regresi dapat digunakan untuk Pelaporan Kerusakan Risiko Prosedur karena nilai signifikansi lebih kecil dari 0,05 (sig $<5 \%$ ). Maka dapat disimpulkan Hipotesi diterima yang menunjukkan bahwa terdapat pengaruh yang signifikan antara X1; Peran inti IA dalam ERM, X2; Peran IA yang legitimate, X3; Roles IA tidak harus melakukan, X4; Hubungan antar Komite Audit dan Audit Internal yang Kuat. X5; Hubungan antar
Komite Audit yang lemah berpengaruh secara bersama-sama atau simultan terhadap pelaporan kerusakan risiko prosedur.

\section{Uji Signifikansi Parameter Individual (Uji Statistik t)}

Dari hasil pengujian terhadap asumsi klasik, diperoleh model tersebut telah memenuhi asumsi normalitas, multikolinearitas, autokorelasi dan heteroskedastisitas. Pengujian hipotesis dilakukan dengan menguji model persamaan regresi secara parsial terhadap masing-masing variabel 
bebas. Uji statistik t bertujuan untuk mengetahui seberapa jauh pengaruh variabel independen secara individual (parsial), yaitu leverage, kualitas audit, dalam menerang- kan variabel dependen yaitu Abnormal Arus Kas. Model regresi pada penelitian ini diuji dengan melihat nilai sig yang terdapat pada tabel 4 berikut ini.

Tabel 4. Uji-t.

\begin{tabular}{|c|c|c|c|c|c|c|}
\hline & \multirow[t]{2}{*}{ Model } & \multicolumn{2}{|c|}{$\begin{array}{c}\text { Unstandardized } \\
\text { Coefficients }\end{array}$} & \multirow{2}{*}{$\begin{array}{c}\text { Standardized } \\
\text { Coefficients }\end{array}$} & \multirow[t]{2}{*}{$\mathrm{t}$} & \multirow[t]{2}{*}{ Sig. } \\
\hline & & $\mathrm{B}$ & Std. Error & & & \\
\hline \multirow[t]{6}{*}{1} & (Constant) & -.488 & .997 & & -.489 & .628 \\
\hline & AVEX1 & .380 & .222 & .284 & 1.716 & .096 \\
\hline & AVEX2 & -.287 & .244 & -.167 & -1.176 & .248 \\
\hline & Avex3 & .317 & .163 & .231 & 1.940 & .062 \\
\hline & AveX4 & .387 & .177 & .386 & 2.193 & .036 \\
\hline & AveX5 & .340 & .255 & .259 & 1.332 & .193 \\
\hline
\end{tabular}

Berdasarkan hasil uji statistik t pada tabel 4 di atas, maka diperoleh persamaan regresi sebagai berikut:

Pelp. Ker. Prosedur Risiko $=-\mathbf{0 . 4 8 8}+$ 0,380X1-0,287X2 + 0,317X3 + 0,387X4 $+0,340$ X5 $+\varepsilon$

Dari persamaan regresi di atas, diketahui bahwa konstanta sebesar -0,488 menyatakan bahwa apabila variabel independen yang terdiri dari X1; Peran inti IA dalam ERM, X2; Peran IA yang legitimate, X3; Roles IA tidak harus melakukan, X4; Hubungan antar Komite Audit dan Audit Internal yang Kuat. X5; Hubungan antar Komite Audit yang lemah, maka Pelaporan Kerusakan Risiko Prosedur dengan arah negatif. Hal ini berarti variabel independen yang terdiri dari $\mathrm{X} 1$; Peran inti IA dalam ERM, X2; Peran IA yang legitimate, X3; Roles IA tidak harus melakukan, X4; Hubungan antar Komite Audit dan Audit Internal yang Kuat. X5; Hubungan antar Komite Audit yang lemah artinya variabel independen yang lemah terhadap variabel pelaporan Kerusakan Risiko Prosedur.

\section{Pembahasan Hasil Penelitian}

\section{a. Pengaruh Peran Inti IA dalam ERM terhadap Prosedur Pelaporan Kerusakan Prosedur Risiko}

Pengujian hipotesis mengenai penggu- naan Peran inti dalam implementasi ERM dalam Prosedur Pelaporan kerusakan Risiko memperlihatkan nilai koefisien regresi sebesar 0,380 dengan nilai nilai $t$ hitung sebesar 1,716 yang berada diatas 0,05 . Hal ini berarti bahwa variabel X1: Peran inti Internal Audit tidak memiliki pengaruh yang signifikan dalam hal Prosedur Pelaporan Kerusakan Risiko

\section{b. Pengaruh Peran IA yang Legitimate terhadap Prosedur Pelaporan Kerusakan Prosedur Risiko}

Pengujian hipotesis mengenai penggunaan variabel Peran Internal Audit terhadap Prosedur Pelaporan Kerusakan Risiko memperlihatkan koefisien regresi sebesar -0,287 dan nilai t hitung sebesar -1,176 dengan nilai signifikansi sebesar 0,248. Hal ini berarti bahwa Peran IA yang legitimate tidak memiliki pengaruh yang signifikan terhadap pelaporan Kerusakan Risiko Prosedur Audit.

\section{c. Pengaruh Role IA yang tidak harus dilakukan terhadap Prosedur Pelaporan Kerusakan Risiko}


Pengujian hipotesis mengenai penggunaan Role IA ya ng tidak harus dilakukan terhadap Prosedur Pelaporan Kerusakan Risiko memperlihatkan koefisien Regresi sebesar 0,317 dan nilai t hitung sebesar 1,940 dengan nilai signifikansi 0.062 . Hal ini berarti Role IA yang tidak harus dilakukan tidak memiliki pengaruh yang signifikan terhadap Prosedur Pelaporan Kerusakan Risiko.

\section{d. Pengaruh Hubungan Antar Komite Audit dan Audit Internal Audit yang Kuat terhadap Prosedur Pelaporan Kerusakan Risiko}

Pengujian Hipothesis mengenai Hubungan Komite Audit dan Audit Internal terhadap Prosedur Pelaporan Kerusakan Risiko mempunyai koefisien regresi sebesar 0,340 dan nilai t hitung sebesar 2,193 dengan nilai signifikansi adalah 0,036. Maka hal ini berarti bahwa Hubungan Komite Audit dan Audit Internal memili pengaruh yang sangat kuat terhadap Prosedur Pelaporan Kerusakan Prosedur.

\section{e. Pengaruh Hubungan Antar Komite Audit yang Lemah terhadap Prosedur Pelaporan Kerusakan Risiko}

Pengujian Hipothesis mengenai Hubungan Komite Audit dan Audit Internal yang lemah terhadap Prosedur Pelaporan Kerusakan Risiko mempunyai koefisien regresi sebesar 0,387 dan nilai t hitung sebesar 1,332 dengan nilai signifikansi adalah 0,193. Maka hal ini berarti bahwa Hubungan Komite Audit dan Audit Internal yang lemah tidak memiliki pengaruh terhadap pelaporan Kerusakan Prosedur Risiko.

\section{Kesimpulan}

Berdasarkan hasil analisis dan pembahasan yang telah dijelaskan di bab sebelumnya, maka kesimpulan dari penelitian ini adalah:

1) Hasil statistik menunjukkan bahwa tingkat keterlibatan auditor internal yang tinggi pada implementasi Enterprise Risk Management perusahaan tidak berpengaruh dan signifikan terhadap pelaporan kerusakan prosedur manajemen risiko perusahaan. Hal ini menunjukkan bahwa peran auditor internal dalam manajemen risiko perusahaan tidak mempengaruhi pelaporan kerusakan prosedur manajemen risiko perusahaan.

2) Hasil statistik menunjukkan bahwa karakteristik hubungan yang kuat antara auditor internal dengan komite audit berpegaruh positif dan signifikan terhadap pelaporan kerusakan prosedur risiko perusahaan. Hal ini menunjukkan bahwa karakteristik hubungan antara auditor internal dengan komite audit berpengaruh terhadap pelaporan kerusakan prosedur risiko perusahaan. Hasil statistik menunjukkan bahwa audit internal yang memiliki hubungan audit internal-komite audit yang kuat akan sangat mendukung internal auditor yang memiliki keterlibatan yang tinggi untuk melaporkan kerusakan prosedur risiko yang lebih besar.

\section{Implikasi Penelitian}

Dengan adanya penelitian ini, diharapkan hubungan koordinasi kerja yang baik antara internal audit dan komite audit dalam suatu entitas dalam pelaksanaan Enterprise Risk Management berupa melaporkan kerusakan prosedur risiko, akan memiliki keterlibatan yang lebih tinggi dalam menyampaikan informasi kerusakan prosedur risiko tersebut kepada manajemen. Sehingga manajemen dapat mengantisipasi kemungkinan terjadinya kesalahan dengan dalam kerusakan prosedur dapat diminimalisasi.

\section{Keterbatasan Penelitian}

Penelitian ini memiliki beberapa keterbatasan, antara lain, Pertama pemisahan kelompok keterlibatan maupun hubungan hanya didasarkan pada nilai rata-rata karena tidak ada patokan yang jelas. Kedua, penelitian sejenis di Indonesia masih sangat jarang sehingga menyulitkan untuk pencarian 
bahan perbandingan dan referensi.

\section{Daftar Pustaka}

Adamec, B. A., Leinicke, L. M., Ostrosky, J. A. and Rexroad, W. M., (2005). "Getting a leg up", Internal Auditor, Vol. 62 No. 3.pp 40-5.

ASX Corporate Governance Council, 2007. Corporate Governance Principles and Recommendations, 2nd ed., Sydney: ASX.

Bailey, J. A., (2007). "Best practices for internal auditor independence", Internal Auditing, Vol. 22 No. 2, pp. 34-7.

Blue Ribbon Committee, 1999. Report and Recommendations, Blue Ribbon Committee on Improving the Effectiveness of Corporate Audit Committees, New York Stock Exchange, New York, NY.

Brody, R. G. and Lowe, D. J., (2000). "The new role of the internal auditor: implications for internal auditor objectivity", International Journal of Auditing, Vol. 4 No. 2, pp. 169-76.

COSO, 2004. Internal Control - Integrated Framework, Executive Summary, Committee of Sponsoring Organisations, available at: www.coso.org/documents/ COSO_ERM_ExecutiveSummary.pdf. (accessed 7 June 2006)

DeZoort, F. T., Hermanson, D. R., Archambeault, D. S. and Reed, S. A., (2002). "Audit committee effectiveness: a synthesis of the empirical audit committee literature”, Journal of Accounting Literature, Vol. 21 No. 2, pp. 38-75.

Donnelly, D. P., Quirin, J. J. and O’Bryan, D., (2003). "Auditor acceptance of dysfunctional audit behavior: an explanatory model using auditors' personal characteristics", Behavioral Research in
Accounting, Vol. 15 No. 1, pp. 87-110.

Ghozali, Imam, 2011. Aplikasi Analisis Multivariate dengan Program SPSS. Semarang: Badan Penerbit Universitas Diponegoro.

Gul, F. and Subramaniam, N., (1994). "Audit committee, gifts and discounts, and familiarity as factors affecting internal auditors' professional objectivity", The Review of Business Studies, Vol. 3 No. 1, pp. 89-99.

IIA, (2004a). "COSO releases new ERM framework", available at: www.theiia. org/guidance/additional-esources/cosorelated-resources/coso-releases-new-erm -framework/. (accessed 20 September 2011).

IIA, (2004b). "The role of internal auditing in enterprise risk management", available at: www.iia.org.au/technical Resources/knowledgeitem.aspx?ID1/432. (accessed 20 September 2011).

Larrick, R. P., (1993). "Motivational factors in decision theories: the role of selfprotection”, Psychological Bulletin, Vol. 113 No. 3, pp. 440-50.

McNair, C. J., (1991). "Proper compromises: the management control dilemma in public accounting and its impact on auditor behaviour”, Accounting, Organization, and Society, Vol. 16 No. 7, pp. 635-53.

Messier, W. And Quilliam, W., (1992). “The effect of accountability on judgment: development of hypotheses for auditing", Auditing: A Journal of Practice \& Theory, Vol. 11, pp. 123-52 (supplement).

Sarens, G. and De Beelde, I., (2006). "Internal auditors' perception about their role in risk management: a comparison between US and Belgian 
companies", Managerial Auditing Journal, Vol. 21 No. 1, pp. 63-80.

Stefaniak, C and Robertson, J. C.,(2010). "When auditors err: how mistake sig- nificance and superiors' historical reactions influence auditors' likelihood to admit a mistake", International Journal of Auditing, Vol. 14, pp. 41-55. 